\title{
The Miniature World in the Genealogy of Yoknapatawha- The Superficial View on Faulkner's Novelettes
}

\author{
WANG Shuang, CHEN Qiang \\ Changchun University, Changchun, China
}

\begin{abstract}
Some of William Faulkner's works were backgrounded by the fictitious county of Yoknapatawha in northern Mississippi, hence were called the genealogy of Yoknapatawha. His long novels were no doubt the main parts of the genealogy of Yoknapatawha, while we cannot ignore his novelettes which had the same background. Focusing on several aspects such as the Southern Spirit reflected from the works, the conflict between the South and the North, and the images of southern personage, this paper comes to analyze Faulkner's novelettes, thus revealing their respective characteristics, abundant intensions, and the close relationship with the genealogy of Yoknapatawha. I hope that we can have a more overall understanding and comprehension of Faulkner's works through the superficial analysis in this paper.
\end{abstract}

Keywords: the genealogy of Yoknapatawha, Southern Spirit, conflict between the South and the North, images of southern personage

\section{Introduction}

William Faulkner (1897-1962) was one of the most important modern novelists in the United States. As the main representative of American southern literature, he has got better and better comments in the American world of literature and art since getting the Nobel Prize for literature in 1949. Up to now, he has been a major focus being studied and commented upon in literary circles.

Faulkner created 19 long novels and 75 short stories, most of which have reflected the local conditions and customs in the southern USA. Most of the backgrounds of the novels lie in the fictitious county of Yoknapatawha in northern Mississippi. The characters are mostly the local residents. Faulkner's works are deeply rooted in the southern USA and the incarnation of the hometown in his mind-Yoknapatawha. His novelettes do not merely intersect and coincide with the content in his long novels. The important factors of the genealogy of Yoknapatawha, such as the Southern Spirit, the conflict between the South and the North, and the distinct images of southern personage, which are represented in his novelettes, are enlisted in the whole genealogy of Yoknapatawha as long works too. Therefore, in addition to Faulkner's famous long works, his short stories are worth our careful studying and summarizing as well.

\section{The Southern Spirit}

Faulkner has displayed southern people’s outstanding spiritual quality and moral sentiment known as

WANG Shuang, lecturer, master, Public Foreign Languages Teaching and Research Department, Changchun University.

CHEN Qiang, associate professor, Ph.D. candidate, Public Foreign Languages Teaching and Research Department, Changchun University. 
Southern Spirit in the novel. Meanwhile, seen from another point of view, the display of Southern Spirit is extolling the whole human spiritual wealth as well. So among the whole works in the genealogy of Yoknapatawha, Southern Spirit is one important clue that penetrates from the beginning to the end, which is in conformity with the writer's original creation intention.

In their specific historical and geographical environment, southern people have cultivated a special emotion about land and nature. As the pioneers of the borderland and the explorers of the wilderness, they irrigate their own homeland with their industrious sweat. During long-term agricultural production and the hunting activities, they come to learn the importance of land and nature by contacting with them. Nature and land have determined the southerner's mental outlook just as parents, so the most outstanding representation of Southern Spirit is the respect and love of nature and land. Their valiant and industrious spirit to bear hardship is shown during contact with nature and land.

Another important aspect of Southern Spirit is the love of hometown and homeland. This kind of affection exists in the southerner's deep soul and is constantly passed down from one generation to another. The southerners are proud of this spirit which is flowing in their body like blood. It is because of the southerner's industry and bravery that they have irrigated the hometowns which they depend on for existence with their sweat. The South, this stretch of land, is full of people's ideals and faiths of many generations, which they are willing to devote everything to defending without the fear of sacrifice. The southerners come to abide by and pursue their outstanding qualities such as honor, pride, and principle out of their love of homeland. They pay more attention to people's moral character, the sterling value, and the meaning of people's life. They also attach importance to the position of the human emotion in one's life such as love, friendship, and kindred, which is an important aspect of the outstanding morality in the South. The love of homeland is not only confined to the South, but it can sometimes surmount the regional idea, becoming the love of the whole motherland. This is also the concept of value that Faulkner affirmed when getting the Nobel Prize.

In Faulkner's short stories, there are a lot of concerns on the excellent moral quality of the South. The reverence for the nature and the land demonstrates the southern people's valiant and industrious spirit to bear hardship; and the love of the homeland demonstrates their pursuit of honor and the noble understanding of the value of life. Meanwhile the writer also emphasizes that these outstanding moralities not only belong to the South, they also belong to the entire United States as well as the whole mankind.

\section{The Conflict Between the South and the North}

A series of stories in the genealogy of Yoknapatawha mostly took place before or after the Civil War, during which a series of incidents such as the breaking out of the Civil War, the failure of the South, the establishment of the New South and the first and the second World War, etc. have had an enormous impact on the South. With the original self-sufficient agricultural mode of production, the plantation economy and slavery broken, the South was forced to enter the western modern society from the traditional society. During this course, all respects of the southern production and life have changed unprecedentedly, integrating with "civilization" in the North progressively. This has brought the problem of contradiction and conflict between the South and the North: the conservation in the South and the progress in the North; the traditional morals in the South and the industrial civilization in the North. All sorts of differences were rubbing and colliding constantly. The South at that time was under a kind of special historical background, seeming to come to the crossroads in the face of great turn. The inexorable declining trend of the southern economic and political 
system has not merely been represented in the long works, but in his short works, the representation of this kind of theme is equally excellent. According to the three respects of economy, politics, and concept, we can analyze the contradiction and conflict which the writer wants to display.

Firstly, the most radical difference between the South and the North lies in their different economic systems. The mechanical industrial civilization in the North has already permeated through the land in the South via extensive channels. In contrast, the original agricultural mode of production seems to lag behind. In this case, it is bound to have a strong impact on the original notions of labor and the concepts of life.

Secondly, the political systems in the South and the North are two incompatible sides as fire and water during the Civil War. As a vivid historical picture, Faulkner's novelettes have a vivid description of it which you can see clearly in the story "My grandmother Millard, General Bedford • Forrest and the Harry Gold River War”. The story fully demonstrated the southern plantation owners' attitudes toward the Civil War. The grandmother, General Forrest and others' attitudes toward the northern army clearly illustrate the political conflict of the South and the North. Another novelette, "Immortality", also reflects the inconsistent political ideas of the North and the South. The background of the story occurred during World War II, when the Civil War has ended for a long time, and the North and the South have been unified. However, different political concepts still exist in the depths of the people's heart.

Thirdly, the contradiction and conflict between the South and the North can be briefly summarized as the great difference in the concept of value. The contrast between northern mechanical industrial civilization and the southern idyllic life has led to the situation that the people treated human beings, activities, and the attitudes towards life in a great different way. What to pursue and how to live during one's life seem to be an important respect that Faulkner wants to represent in his novels.

In the story "Lofty People", Faulkner revealed the conflicting mode of thinking and concept of value. Faced with the impact of industrial civilization, the author is more inclined to the old southern farmers' honest ideas and the concept of freedom.

Obviously, Faulkner's storytelling country fellows believe that the last few lofty people who have the spirit of endurance and who resist the forces of the outside corrosion, are able to teach us how to recover our conscience. Of course, they do not mean tall stature, but to the moral level, which is a reflection of pride and dignity.

And this is the real meaning of the story.

\section{The Distinct Images of Southern Personage}

Faulkner has constructed the genealogy of Yoknapatawha which is in sharp contrast to the metropolitan culture of the 20th century. Here is a kind of agricultural economy, a kind of life in farms, villages, and small towns which has a set of old value standards, a kind of religion that still has vitality and has its etiquette, religious doctrine, and basic behavioral norms. Having constructed such a kind of environment, Faulkner has not only represented the local conditions and customs in the South, but also modelled a large number of typical images of the southern personage, including the white feudal lords in the plantation, the black slaves, the American Indians, and the white peasants in the countryside. In his long novels, Faulkner has created some typical images such as the Compson family, The Sedpan family, Sam Fazesi and Walsh, etc.. As an indispensable component of the Yoknapatawha, his series of novelettes still focused on these characters and continued their stories. Several short stories concentrating on the description of Black and American Indians, 
not merely represent the living conditions of these kind of people, but also recovered the relationship among the American Indians, the Blacks, and the Whites, which makes us possess a further understanding of the life in Yoknapatawha. Hence, we may safely draw the conclusion that Faulkner's novelettes concerning the Indians and the Black are in no way inferior to his voluminous works when it comes to the depth of ideology. They are short and pithy, concise and vivid when portraying characters, hence may better reflect the writer's superb artistic level. They are really the important and indispensable component in the whole genealogy of Yoknapatawha.

\section{Conclusion}

Faulkner's genealogy of Yoknapatawha is his abundant creative source. Having created it, giving it the broadness and vigor of life, drawing nutriments constantly from it, that is exactly where his greatness lies. Whether they are his long novels or his short stories, all of his works are rooted in this land deeply and are one part of the genealogy of Yoknapatawha.

\section{References}

DONG, H. Z. (1987). On modern American novelists. Beijing: Chinese Social Sciences Press.

Faulkner, W. (1985). The anthology of Faulkner's novelettes. World Literature Editorial Department (Ed.). Beijing: Chinese Federation of Literature Publishing Company.

Hoffman, D. (1984). Contemporary American literature. World Literature Editorial Department (Ed.). Beijing: Chinese Federation of Literature Publishing Company.

LI, W. J. (1980). The anthology of the comments on Faulkner. Beijing: Chinese Social Sciences Press.

Mint, D. (1991). The biography of William Faulkner (Y. ZHAO, Trans.). Beijing: SDX Joint Publishing Company.

Weinstein, P. M. (Ed.). (1995). The Cambridge companion to William Faulkner. Cambridge: Cambridge University Press. 